\title{
Cikkismertetés: Az egészség kereskedelmi meghatározói
}

\section{Article review: Commercial determinants of health}

\author{
Ismertető: \\ Tarkó Klára \\ Ismertetett cikk: Maani, N., Collin, J., Friel, S., B Gilmore, A., McCambridge, J., Robertson, L. and P \\ Petticrew, M. (2020). Bringing the commercial determinants of health out of \\ the shadows: a review of how the commercial determinants are represented in \\ conceptual frameworks. European Journal of Public Health, Volume 30, Issue 4., \\ pp. 660-664, doi: 10.1093/eurpub/ckz197 \\ Kulcsszavak: $\quad$ egészség társadalmi meghatározói; egészség kereskedelmi meghatározói; \\ egészségegyenlőtlenségek \\ Keywords: \\ social determinants of health; commercial determinants of health; health inequalities
}

Beküldve: 2021. 07. 03., doi: $10.24365 /$ ef.v62i3.6748

Az „egészséget meghatározó kereskedelmi tényezők" ('commercial determinants of health', $\mathrm{CDOH}$ ) meghatározás a dohány-, alkohol-, élelmiszer- és italgyártóipar és hasonló vállalatok szerepét hangsúlyozza a nemfertőző betegségek kialakulásában. Ezek a tényezők mintha nem kapnának kellő hangsúlyt, amikor az egészséget meghatározó társadalmi tényezőkről van szó. Ez a gondolat indította a szerzőket arra, hogy megvizsgálják az egészséget meghatározó tényezőket magukba foglaló létező keretrendszereket, hogy azok tartalmazzák-e, és ha igen, milyen módon az egészséget meghatározó kereskedelmi tényezőket.

A szerzők a dokumentumelemzés módszerét alkalmazták. A "társadalmi meghatározók" és "keretrendszer" keresőparaméterek alkalmazásával a Medline-on 2000. január 1. és 2017. szeptember 6. között megjelent tudományos cikkek közül választottak ki 615 tanulmányt, majd pedig a Google Scholar és a kiszűrt tudományos cikkek irodalomjegyzékei alapján azonosítottak nem tudományos jellegű forrásokat (például szakpolitikai dokumentumokat) és 2000 előttről származó keretrendszereket. A kapott lista továbbá kiegészítésre került a szerzők által ismert további keretrendszereket tartalmazó dokumentumokkal. Az elemzendő mintába bekerült minden olyan dokumentum, amely a különféle meghatározók integrálását bemutató fogalmi keret grafikusan megjelenített ábráját vagy diagramját tartalmazta. Azokat a keret- dokumentumokat választották ki, amelyek egyértelmúen rögzítik a népesség egészségi állapota és/vagy az egészség terén mutatkozó egyenlőtlenségek és ezek vonatkozó tényezőinek (az egyénitől a társadalmiig) kapcsolatát.

A dokumentumokból a szerzők a társadalmi meghatározók 48 fogalmi keretrendszerét azonosították, melyek közül csak egyetlen egy tartalmazott egyértelmúen kereskedelmi szereplőket, mégpedig az élelmiszeripar vonatkozásában és táblázatos formában megjelenítve. 10 olyan tanulmányt találtak, amelyben valamilyen formában szó esett a kereskedelmi meghatározókról, és 14 olyat, amely a vállalati befolyásra vagy a negatív hatásokra hozott példát. 12 tanulmány tárgyalta a magánszektor pozitív, egészségjavító szerepét, vagy szövegesen és/vagy ábra formájában.

A vizsgált keretrendszerek többségében csak kismértékben vagy egyáltalán nem ismerték fel a kereskedelmi szereplők egészségre gyakorolt hatásának, vagy abban játszott szerepének jelentőségét, inkább a tágabb értelemben vett strukturális meghatározókra fókuszáltak, olyan általános kifejezések használatával, mint a "gazdasági meghatározók". Még azokban az esetekben is, amikor a gazdasági tevékenység és a kereskedelem szerepelt egy fogalmi ábrában, a hangsúly általában az általános makroökonómiai környezetre került, és nem arra, hogy az egyes kereskedelmi szereplők, például a transznacionális 
vállalatok hogyan befolyásolhatják a kereskedelmi megállapodásokat, ösztönözhetik a fogyasztói keresletet, biztosíthatják a foglalkoztatást, alakíthatják a munkakörülményeket, alakíthatnak ki partnerséget az állami szektor vállalataival, nyújthatnak egészségügyi szolgáltatásokat vagy befolyásolhatják a szakpolitikát és a szabályozókat. Olyan keretrendszerek is akadtak, amelyek egyáltalán nem tartalmazták a gazdasági meghatározókat.

Néhány esetben, ha szerepeltek is kereskedelmi tényezők a szövegben indirekt módon, például a dohányzás vagy az alkoholfogyasztás említésével, ezek életmódbeli tényezőkként kerültek feltüntetésre, nem említve a fogyasztásukat ösztönző (hozzáférhetőség, ár, reklám) kereskedelmi szereplőket.

Bár a kereskedelmi tényezők általában nem jelennek meg a fogalmi ábrákban, 10 tanulmány esetében a szöveges leírás azonban hosszabban tárgyalja azokat. Például a jól ismert Dahlgren és Whitehead-féle szivárvány modell tárgyalja a globalizációt és a főbb pénzügyi szereplők befolyását, valamint konkrét hivatkozásokat közöl az egyenlőtlenségeket előidéző kereskedelmi meghatározók kapcsán. A kutatás alapján egyértelmúen bebizonyosodott, hogy a kereskedelmi szereplők fontossága alábecsült, nem jelennek meg egyértelműen, vagy egyenesen hiányoznak az egészség társadalmi meghatározóit leíró legtöbb jól ismert fogalmi keretrendszerből. Ez főként azoknak a keretrendszereknek az esetében a legszembetűnőbb, ahol a vállalati befolyás potenciálisan jelentős befolyással bírhat például egy, a gyermekkori fogszuvasodás kapcsán kidolgozott keretrendszer esetében, amely nem tartalmazza a cukros termékek marketingjének szerepét. A kereskedelmi meghatározók láthatatlansága és kimaradása a keretrendszerekből azért jelent problémát, mert elkendőzi a kereskedelmi szektor felelősségét és hozzájárulását az egészségegyenlőtlenségekhez és a lakosság egészségkárosodásához, és más társadalmi meghatározókra tereli a figyelmet, aminek következtében a politikaalkotók, a gyakorló szakemberek és a kutatók figyelme nem a megfelelő tényezőkre fog irányulni.

A szerzők következtetése szerint a népegészségügynek minél előbb újra kellene gondolnia a társadalmi meghatározók meglévő keretrendszereit, nagyobb hangsúlyt fektetve az egészség kereskedelmi meghatározóira. Arra is szükség van, hogy a politikai döntéshozók megköveteljék, hogy a nagy befolyással bíró kereskedelmi szereplők felelősséget vállaljanak a tevékenységükért. Ennek hiányában a magánszektornak, különösen a nagy transznacionális vállalatoknak az egyéni magatartást és a lakosság egészségi állapotát befolyásoló szerepe rejtve marad.

\section{TANULSÁGOK A HAZAI SZAKEMBEREK SZÁMÁRA}

Egészségünket számtalan tényező befolyásolja, melyek közül a társadalmi meghatározók játszák a legfontosabb szerepet. Minden társadalmi változás, legyen az kedvező vagy kedvezőtlen irányú, hatással van arra, ahogyan élünk, milyen objektív körülményekkel rendelkezünk, milyen lehetőségekkel bírunk és milyen választásokat teszünk magunk és környezetünk érdekében. Folyamatosan szembesülünk a bennünket bombázó hangzatos kereskedelmi hirdetésekkel, melyek egy jobb élet, az egészség ígérete vagy éppen a spórolás jegyében vesznek rá bennünket egy-egy termék megvásárlására, egy pozitívum kiemelésével, és az azt gyakorlatilag lenullázó számos negatívum elhallgatásával. A kereskedelmi hirdetések útvesztójében még azok is eltévedhetnek, akik kielégítő egészségmúveltséggel rendelkeznek, az egészségműveltségben (is) meglévő egyenlőtlenségek pedig predesztinálják, hogy az egészségünk szempontjából nem mindig pozitív döntést hozzunk. Az egészségmúveltség növelése mellett így valóban nagyon nagy felelőssége van azoknak a kereskedelmi szereplőknek is, akik termékeiket reklámozzák, valamint azoknak a hatóságoknak és politikaalkotóknak is, akik szabályozzák és felügyelik e reklámok valóságtartalmát.

Információk a szerzőről:

Tarkó Klára, Szegedi Tudományegyetem Juhász Gyula Pedagógusképző Kar, Alkalmazott

Egészségtudományi és Környezeti Nevelés Intézet, tarko.klara@szte.hu 